\author{
Karimova B., ${ }^{1}$ Tuyakbayev . $^{2}$ \\ ${ }^{1,2}$ Kyzylorda State University named after Korkyt Ata, \\ Kyzylorda, Kazakhstan
}

\title{
MUSTAFA SHOKAY IS THE FOUNDER OF KAZAKH EMIGRANT JORNALISM
}

\begin{abstract}
The article deals with the formation and history of Kazakh emigrant journalism. The author emphasizes the relevance of the study of the history of the formation and development of Kazakh emigrant journalism in the context of the concepts of diaspora, emigrants, irridents, based on the research in political sciences. It is recommended to consider publications in Kazakh language published in and abroad in terms of the status of emigrant publications and Kazakh language publications abroad, analysing the history and direction of their publication.

Mustafa Shokay was public and political figure. He has special place in our national history. Analyzing his editorial and journalistic works he is portrayed as a founder of Kazakh emigrant journalism. According to sources, he used the media as the main political tool in the struggle for the unity and freedom of Turkic people, and himself initiated the emergence of several emigrant publications.
\end{abstract}

Keywords:emigrant, diaspora, irrident, emigrant journalism, publication, language

$$
\begin{gathered}
\text { Каримова Б.С., }{ }^{1} \text { Тұяқбаев Ғ.А. } \\
{ }^{2} \\
{ }_{1,2} \text { Қорқыт Ата атындавы Қызыллорда мемлекеттік университеті, } \\
\text { Қызылорда, Қазақстан }
\end{gathered}
$$

\section{МҰСТАФА ШОКАЙ ҚАЗАҚ ЭМИГРАНТТЫК ЖУРНАЛИСТИКАСЫНЫН НЕГІЗІН ҚАЛАУШЫ}

\section{Аңцдатпа}

Мақалада қазақ эмигранттық журналистикасының қалыптасуы мен тарихы туралы сөз болады. Автор саяси ғылымдардағы зерттеулерді негізге ала отырып диаспора, эмигрант, ирридент ұғымдары аясында қазақ эмигранттық журналистикасының қалыптасуы мен даму тарихын зерттеудің өзектілігіне тоқталады. Шетелдерде жарық көрген және шығатын қазақ тілді басылымдарды шығу тарихын, ұстанған бағыт-бағдарын саралай отырып, эмигранттық басылымдар және шетелдердегі қазақ тілді басылымдар деген мәртебе тұрғысынан қарауды ұсынады.

Ұлттық тарихымызда ерекше орны бар қоғам және саяси қайраткер Мұстафа Шоқайдың редакторлық, публицистік еңбектеріне талдау жасай келе, М.Шоқайды қазақ эмигранттық журналистикасының негізін қалаушы ретінде көрсетеді. Оның түркі халықтарының бірлігі мен азаттығы үшін күрес жолында ақпарат құралдарын басты саяси құрал ретінде пайдаланғандығы, өзі де бірнеше эмигранттық басылымдардың өмірге келуіне бастамашы болғандығы дерек көздерін негізге ала отырып ашылған.

Түйін сөздер: журналистика, радио, мерзімді басылымдар, эмигрант, диаспора, ирридент, эмигранттық журналистика, жанр, тәуелсіздік, тіл, мәдениет, дәстүр, азаттық, күрескерлік

$$
\text { Каримова Б.С., }{ }^{1} \text { Туякбаев Г.А. }{ }^{2}
$$

${ }^{1,2}$ Кызылординский Государственный Университет им. Коркыт Ата, Кьзылорда, Казахстан

\section{МУСТАФА ШОКАЙ - ОСНОВАТЕЛЬ КАЗАХСКОЙ ЭМИГРАНТСКОЙ ЖУРНАЛИСТИКИ}

\section{Аннотация}

Статья посвящена становлению и истории казахской эмигрантской журналистики. Автор подчеркивает актуальность изучения истории становления и развития казахской эмигрантской журналистики в контексте концепций диаспоры, эмигрантов, ирридентов, основанных на исследованиях в области политических наук. Рекомендуется рассматривать издания на казахском языке, издаваемые в стране и за рубежом, с точки зрения статуса эмигрантских изданий и изданий на казахском языке за рубежом, анализируя историю и направление их издания.

Мустафа Шокай был общественным и политическим деятелем. Он занимает особое место в нашей национальной истории. Анализируя свои редакционные и публицистические работы, он предстает как основоположник казахской эмигрантской журналистики. По данным источников, он использовал средства массовой 
информации как главный политический инструмент в борьбе за единство и свободу тюркского народа, а также сам инициировал появление нескольких эмигрантских изданий.

Ключевые слова: эмигрант, диаспора, ирридент, эмигрантская журналистика, публикация, язык

Introduction. According to researchers, nowadays in more than 40 countries around the world there are approximately three and a half million Kazakhs. There are different ways and reasons for migration from their homeland. Political science considers those Kazakhs who are abroad as diaspora, irridents and emigrants due to the reasons of settlement and migration from historical homeland. Diaspora is the relocation of a certain part of the population to another country due to economic, geographical and political factors [1,239]. An emigrant is an involuntary migrant from his homeland due to political , economic, religious and other issues, irrident is a part of the population living in their historical homeland, but remaining in another state due to certain political circumstances [2,162]. If we apply these definitions to Kazakh people, we can say Irrigations of Kazakh people living in Astrahan, Orenburg, Qorgan, Omby, Altay Autonomous region in Russia; Altai, Tarbagatai, Ile, Qulja in China; Bayan-Ulgii region in Mongolia; Syrdarya, Shyrshyq, Qyzylqum, Myrzashol districts in Uzbekstan. Kazakhs who were forced to emigrate from China, Mongolia, Central Asia to European countries due to political, historical or other circumstances, should be called emigrants.

Russian scholars also distinguish between the status of the diaspora and migration. Tishkov offers his version 'The diaspora is a place of migration under the influence of political influence, while migration is dominated by the social situation' [3, 42-63]. A. Zelenin's offer is 'Those who emigrated from Russia before 1917 were migrants and those who emigrated after 1917 were emigrants. They formed Russian diaspora in the early twentieth century. They formed Russian diaspora in the early twentieth century [4.30].

Since the independence time, more than twenty years the sciences of history, cultural studies, ethnography, philosophy, literary criticism, linguistics began to be studied the lifestyle, ethnography, language, literature of our compatriots abroad. Researchers of the history of journalism are not left out of this topical issue in national science. We can call as innovative researches the works on Kazakh publications published in and aboard as works of R.Sh. Nuriden (International Radio Journalism. Almaty. 2012) R.Sharipovna (Foreign Radios Broadcasting in Kazakh. Almaty. 1997), Baimolda (Radio Liberty. History and Experiences. Almaty. 2009), In the works of N.Omashev and Sh.Begimtaeva (Modern foreign journalism. Almaty. 2000). Several candidate dissertations were also defended on these issues. However, this does not mean that Kazakh publications published abroad have been fully studied. There are still issues in the history of journalism that need to be studied in detail. One of them is Kazakh emigrant journalism. The first and most fundamental research in this area is the monograph "The person recognized by the world" of Doctor of Historical Sciences, Professor K.Esmagambetov. (Almaty, 2008).

1. Literature review. While political science considers our compatriots living abroad in terms of the status of the diaspora, emigrants, irridents, studying the history and principles of publications published in Kazakh-language abroad and to determine their status in terms of emigrant publications and Kazakh-language publications abroad is one of needs for the history of journalism. As not all publications published abroad can be considered as emigrant publications.

The history of Kazakh emigrant press is directly connected with the name of Mustafa Shokay. He understood the importance of newspapers and magazines in the political struggle even before emigration. Therefore, he took an active part in publication of newspaper "Birlik Tui" and in the identification of its direction. Unfortunately, the newspaper published in Tashkent in 1917 was closed a year later in the middle of April in 1918 [5,75]. At the same time, M.Shokay was the member of editorial board of the newspaper "Ulig Turkistan" that began to publish from April in 1917 at the initiative of National Center of Muslims of Turkestan region. And also he actively participated in the work of the newspaper. The newspaper publised several articles according to the unity of Turkic people, the colonial policy of newly established Soviet government, land, national liberation and liberty. Although, as the editor of newspaper was Fatih Keremi, Tatar from Kazan, we can see that M.Shokay's opinion prevailed in determining the main position of the publication. From these two editions we can recognize M.Shokay's journalistic, publistic, editorial and organizational skills. Mustafa Shokay was forced to leave the native country realizing from the first day of its establishment that the Soviet government would not allow any democratic movements and also the new state was a legitimate continuation of Tsarist Russia. While in exile, he pursued a political career as a journalist and editor. He uses the media as the main weapon in the struggle for national liberation.

Arriving in Tbilisi in April 1919 M.Shokay participated in the publication of newspapers in Russian "Abroad" and in Turkish "Shafak". However, both publications were closed after the establishment of the Soviet goverment in the Caucasus. Realizing the danger of staying in the Caucasus M.Shokay moved to Paris in May 1921. But he seems to be hesitant if he would stay in one of county of Western Europe or move to the United States. In 1922 he visited Italy.He spent six month of 1923 year in Germany. At the end Mustafa decided to stay in Paris, the capital of political emigration[6, 225].

At that time Turkey and Paris were the countries with the largest concentration of emigrants from the Central Asia and the Tatar and Bashkurt emigrants had good relations with Turkey. In the second half of the $19^{\text {th }}$ century and the beginning of the $20^{\text {th }}$ century, after the October Revolution of 1917 thousands of Tatars settled in Turkey. A.I. Galyamutdinov is one of the researchers of Tatar emigrant journalism offers his point as "Tatar intellectuals as Y.Akchury, G.Iskhaki, S.Maksudi, G.Battala, A.Z.Validi, R.Rahmati, H.Zubayra and others were forced to move to other countries. Turkey has become their second home" [7]. It is clear that Shokay's main goal in choosing Paris was to continue his struggle with like-minded, oriented political immigrants and to establish closer ties with Turkey. After the arrival to Paris M.Shokay achieved this political goal. He established contacts with the above-mentioned Tatar intellectuals and emigrants of other Turkic people. "In the autumn of 1923, on the initiative of G.Iskhaki, S.Maksudi, G.Battala, G.Teregulov, F.Tokhtarov, I.Akchurin, A.Shafeev, Z.Validi, M.Bokeyhanov and other Tatar, Bashkur and Kazakh emigrants gathered in Berlin. The decision was made to publish the 
magazine "Mili Yul" in Tatar language" [8]. It should be noted that the author of the article mentioning "M.Bokeyhanov" might be M.Shokay. It is known from history that among Tatar, Bashkurt and Kazakh intellectuals there was no political figure named as M.Bokeyhanov. If he referred to Alihan Bokeihanov who had not been in exile in Turkey, Berlin or Paris. On the contrary, we can see through archival documents and historical memories that M.Shokay was in agreement with Tatar and Bashkurt emigrants, including G. Iskhaki, S.Maksudi, I.Akchurin.

Russian emigrants in Paris also acknowledge the comprehensive knowledge of Mustafa writing about his political foresight. Therefore newspaper editorial offices keep their doors open for him. In 1922 M. Shokay was invited to work in two or three publishing houses in Berlin. This is evidenced by the words of M.Shokay in a letter to N.P.Arhangelsky on the $12^{\text {th }}$ of May, 1922: "I edited and published magazines in Russian, pudlished two newspapers in Turkish and was the editor-in-chief of another newspaper in Russian” [6, 281].

Methodology.Due to the policy of Soviet ideology, we have been unaware of legacy of M. Shokay for many years. Only in the post-independence years it was begun to study his legacy, political and military activities, and the period of emigration. Nowadays magazines published by M.Shokay are mentioning and studying just in the history of Kazakh journalism. In fact, the magazines published by M.Shokay in exile should be considered and studied in the context of Kazakh emigrant journalism. The article analyzes the works of foreign and domestic literary critics, historians, political scientists on the history of journalism and identifies the magazines published by M.Shokay as emigrant publication. In addition, conclusions were drawn through the analysis of domestic and foreign archival materials related to the life and journalistic activities of M.Shokay and his political and military career.

Results.No matter where Shokay went, he never gave up the press. He tried to implement his ideas of nationalism and Turkizm through periodicals. His articles were published in French in Prometheus, Orien e Oxidan, articles in English in Asian Review. He published articles in Russian in his fellow student, Russian emigrants as Kerenski "Days" newspaper and Milukov's newspaper as "Latest News". However M.Shokay soon realized that russian democracy could not be a reliable for Turkestan national movement [6, 229]. Therefore, Mustafa with his ideological partner A.Z. Validi raised the issue of opening a publication of Turkestan National Union. A.Z. Validi was Tatar intelectual, who clearly felt the need for and independent publication that could mourn the loss of Turkic people and was a true sympathizer of the whole idea of Turkestan. There was made a decision on the publication of the newspaper, its language and program in May $12^{\text {th }}$ in 1925 [6,281]. In October on the same year this issue was finally discussed and the organization of publication, the organization of funding for it was entrusted to A.Z.Validi as organizer of National Unity of Turkestan [9]. In accordance to this decision the first number of Yeni Turkestan magazine was published in Istanbul in June 1927. About the work of M.Shokay in the publication of the magazine A.Z.Validi's mentions: " Organizing the magazine Yeni Turkestan the role od Shokay was special, Shokaev was the first to earn money and first the idea of publishing a magazine came to Shokaev [10].

The magazine aims to strengthen the unity of language and mentality between the people of Turkestan and people of Turkey. The main purpose was to acquaint the emigrants with the life of Turkestan, their dreams and interests, the national liberation movement of Turkestan, the socio-economic and political situation, Turkish culture [6,282].

Yeni Turkestan plays an important role in spreading the idea of national liberation and Turkic ideasand promoting the spiritual unity of the Turkic people. M. Shokay published articles in the magazine as "Ideological and practical aspects of the Bolshevik national policy in Turkestan", "Soviet hunger policy in Turkestan", "Turkestan is facing famine", "On the national question", "On the state of Turan and others". These articles were valuable at that time as they revealed the true nature of Soviet ideology.

The growing political activity of Turkestans and the the growing demand for national publications require the Turkestan National Unity to have a new publication that will co-operate with the Yeni Turkestan magazine. M.Shokay prepared for its organization sending a representative to Turkestan at his own expense and establishing contacts with people in Afghanistan and Iran. He will be out of France for more than two weeks to raise funds[11].

On December 2, 1926, M.Shokay wrote to his colleagues in Warsaw about the opening of a new edition: "If it is implemented, the publication of the magazine will require me to be free. I attached great importance to this work... We have just started to look for a practical way of national struggle. We do not expect immediate results and do not make such promises... but from the point of view of long-term state interests, our work is already useful [12]. As the result of such work, in December 1929, the first number of the magazine "Young Turkestan" was published in Berlin. This magazine was In Turkish-Chagatai language with Arabic letter and it was funded by the Prometheus Foundation.

Initially, approximately the magazine had 40 pages, and it had only two or three sections. However, it is obvious that each heading served to reveal the content and increase the value of the publication. For example, in the first number of the magazine Politics section the main articles of the editor M.Shokay "Our way", "From Editorial Board 'Young Turkestan", in Literature section The poems of Magzhan Zhumabaev, In News section news from Turkestan were published.

M.Shokay in his main article "Our way" outlined the main tenet of the magazine saying that Bolsheviks wanted to create republics with "type is national, content is socialist" in Central Asia and Kazakhstan, but under the guise of various slogans it openly states that it is a continuation of the former of Tsarist colonial system, Russian chauvinism. In fact, this was the political foresight of M.Shokay. In the article dedicated to the fifth anniversary of "Young Turkestan" (M.Shokay, 1934) "There is not a single source of Turkestan emigration that does not read Young Turkestan. Letters from Arab countries, Turkey, Persia, India, Afganistan, China, The Far East and other countries can be a clear proof of the scale of Young Turkestan and their great respect for it" [13]. 
According to archival data The Turkish ambassador in France to M.Shokay expressed his opinion that Young Turkestan magazine was of great interest in the capital of Turkey and asked him to send the magazine to the embassy regularly [14]. these two archival data prove that the magazine was distributed in several countries and had thousands of readers.

In general, Young Turkestan magazine was the most outstanding work of M.Shokay showing his journalistic, editorial and organizational skills.

K.Esmagambetov is the scientist of studying Shokay according to archival data substantiates the fact that in addition to the above-mentioned magazines Shokay published the magazine "Turkestan". The magazine previously unknown in the history of journalism was published in Germany. The magazine published articles about the life of Turkic emigrants abroad, the socio-economic and political situation in the Central Asian republics, the unity of the Turkic people, the attitude of the Soviet authorities to the colonial nations. One of the main news of the magazine was the publication of new materials on the history and culture of Turkestan in French and German Literature. Political commentaries such as "Soviet Colonies" and "A Conference on Turkestan in Berlin" also differed in content. Unfortunately, the magazine did not last long. The magazine publishing in five numbers from October 1934 till February 1935 was closed. Due to the lack of data we cannot say under what circumstances this publication was closed. It is known that the Turkish state was reluctant to distribute this publication on its territory. With $51^{\text {th }}$ part of Law according to "On publishing” the Foreign Ministry's ban on the entry of the magazine "Turkestan" in Turkey in connection with the publication of harmful articles about our country was issued on 11.12.1934.proposal in letter № 805 by the delegation of the Executive Representatives dated 20/12/1934” . The document signed by the President testifies to this [15]. This was a time when Turkey established and strengthened ties with the USSR. Therefore it is known that the Turkish state was reluctant to spread anti-Soviet view in emigrant press.

M.Shokay began his journalistic career with publications :BirlikTui", "Ulig Turkestan", then founded the magazines "Yeni Turkestan", "Young Turkestan", "Turkestan" and contributed to their formation and development. The magazine has been distributed in several Turkic-speaking and Muslim countries. It is noteworthy that all the magazines founded by M.Shokay are associated with the name of Turkestan. In fact, this is a manifestation of his Turkic dream in his journalistic and editorial work. Most importantly, Shokay laid the foundation to political journalism and Kazakh emigrant journalism through his article on the creation of a common state for the Turkic people, the unity and alliance of the Turkic people awakening of national and militant consciousness.

Conclusion.Studying the history and trends of M.Shokay publications, we can see the following features of emigrant journalism: first, all of the above mentioned media (from magazines opened by M.Shokay to bulletins) were initiated by emigrants, and even they were published with their own funding; secondly, no matter where the emigrant publications were published, he did not propagate the ideology of that state, on the contrary, he focused only on the propaganda of the Kazakh national ideology or the Turkic ideology; thirdly, emigrant publications were published not only in Kazakh, but in the media regardless of the language, mainly national issues: language, religion, customs, traditions and other national values were promoted, and most importantly, the colonial of Soviet government, chauvinistic stance on non-Russian made public; fourthly, the main purpose of such publications was to awaken the national consciousness, to call the colonial nations to the struggle for liberation.

So, not all Kazakh language media outlets abroad were involved in Soviet power and national political issues. Therefore, we can say that emigrant journalism has served to create an independent, free state to inspire national consciousness.

\section{References:}

1 Soviet encyclopedia. Volume 8. Moscow. Publishing.BSE.1972.

2 Soviet encyclopedia. Volume 30. Moscow. Publishing.BSE.1972.

3 V.A.Tishkov. Historical phenomenon of the diaspora // EO. №2. p.p. 42-63. 2000.

4 A.Zelenin. The language of Russian emigrant press. (1919-1939). 2007.

5 K.Aldabergenuli. Zh.Nuskabai. F.Orazbay. The history of Kazakh journalism. Almaty. Rauan. 1996.

6 Complete collection of works by Mustafa Shokay. 12 volumes. "Dike Press” LLP. ALmaty - 2012.

7 The magazine "Milli Ul" (1928-1939) in the system of the Tatar emigrant press. Author's abstract of the dissertation for the degree of Candidate of Philological Sciences. Kazan, 2012.

8 T. Nasyrov. Tatar emigrant press.

9 Central State archive of Republic of Bashkurtstan. F.4917. Description 1-A. L.

10 BROMM. Foundation 4917. List 1. Case 44. page 8.

11 РГВА. ф. 1358 к. оп.3.д,45 б. л.44 (Рос гос военный архив, фонд 1358 книга, опись 3. Дело 45, 44 лист)

12 РГВА. ф. 1358 к. оп.3.д, 45 б. л. 45

13 РГВА.ф.461к.оп.1.д.431.л.174 (Мына белгіленгенді қалай көрсететінін білмедім. Оп, д, л дегендердік тольққ жазылуын берсеніз, түсінбей жатырмын)

14 The personal archive fund of M.Shokay in France. Carton 5. Dossier 2. p.36

15 Turkiye Gumhuriyet Basbakanlik Gumhuriyet Arsivi. Arsiv 080. Dolap

16 Goz 01. Klasor 1197. Dosya 50. Fihrist 57. S.6.

References:

1 Sovetskaia ensiklopedia. Tom 8. Moskva. İzdatelstvo.BSE.1972.

2 Sovetskaia ensiklopedia. Tom 30. Moskva. İzdatelstvo.BSE.1972. 
3 V. A. Tiş̧kov. İstoricheski fenomen diaspory // EO. №2. s. 42-63.2000.

4 A. Zelenin. İazyk ruskoi emigrantskoi presy. (1919-1939). 2007.

5 K. Aldabergenuli, J. Nuskabai, F. Orazbai. İstoria kazahskoi jurnalistiki. Almaty. Rauan. 1996.

6 Polnoe sobranie sochineni Mustafy Şokaia. 12 tomov. TOO "Daik Pres". ALmaty - 2012.

7 Jurnal "Milli Ul" (1928-1939) v sisteme tatarskoi emigrantskoi presy. Avtoreferat disertasii na soiskanie uchenoi stepeni kandidata filologicheskih nauk. Kazän, 2012.

8 T. Nasyrov. Tatarskaia emigrantskaia presa.

9 Senträlnyi gosudarstvennyi arhiv Respubliki Başkortostan. F. 4917. Opisanie 1-A. L.

10 BROMM . Fond 4917. Spisok 1. Delo 44. stranisa 8.

11 RGVA. f. 1358 k. op.3.d,45 b. 1.44 (Ros gos voennyi arhiv, fond 1358 kniga, opis 3. Delo 45, 44 list)

12 RGVA. f. 1358 k. op.3.d, 45 b. 1.45

13 RGVA.f.461k.op.1.d.431.1.174 (Myna belgılengendı qalai körsetetının bılmedım. Op, d, 1 degenderdık tolyq jazyluyn berseñı, tüsınbei jatyrmyn)

14 Lichnyi arhivnyi fond M. Şoke vo Fransii. Korobka 5. Dose 2. str. 36

15 Tureski Gumhuriet Basbakanlik Gumhuriet Arsivi. Arsiv 080. Dolap

16 Goz 01. Klasor 1197. Dosä 50. Fihrist 57. S. 6.

МРНТИ 19.21.07 $\quad$ https://doi.org/10.51889/2020-4.1728-7804.95

\author{
Каримова Б.С., ${ }^{1}$ Тұяқ̧баев Г.А. ${ }^{2}$ \\ 1,2 Қорқыыт Ата атындавы Қызылорда мемлекеттік университеті, \\ Қьзыллорда, Қазақстан
}

МҰСТАФА ШОКАЙ ХАТТАРЫНЫН ТАРИХИ МАНЫЗЫ

Аңудатпа

Мұстафа Шоқай - тұңғыш қазақ эмигранты, шетелдерде саяси эмиграцияда жүріп ұлт бостандығы, мемлекет тәуелсіздігі, түркі халықтарының бірлігі жолында күрескен қоғам қайраткері. Ол Қоқан автономиялық республикасының негізін қалаушы. Кеңестік идеологияның шағын ұлт өкілдері мен олардың саяси қайраткерлеріне деген қысымынан мәжбүрлі түрде шетелге қоныс аударған. 1917 жылы билікке келген большевиктер үкіметіне барынша қарсылық танытып, Орта Азиядағы түркі халықтарын біріктіру жолында күрескен.

Саяси көзқарастары мен ұстанымдарын қазақ, орыс, ағылшын, француз, түрік тілдерінде шетелдік бұқаралық ақпарат құралдарында жариялай отырып, Шығыс, Батыс, Европа мемлекеттерінің саяси қайраткерлеріне өзін саяси күрескер ретінде мойындатқан. XX ғасырдың алғашқы жартысында әлем саясаткерлерімен байланыс орнатқан.

Мұстафа Шоқай шетелдерде жүріп бірнеше саяси-қоғамдық журналдар ашып, өзін публицист, редактор ретінде танытқан. Оның артында публистикалық мақалалары мен естеліктері, түрлі деңгейдегі жиындар мен форумдарда сөйлеген сөздері қалды. Осындай мұраларының арасында М.Шоқайдың саясаткерлермен, ғалымдармен, мемлекет басшыларымен, туған туысқандарымен, өнер адамдарымен жазысқан хаттарының орны ерекше.

Мақалада М.Шоқайдың эпистолярлық мұрасы және оның тарихи маңызы туралы сөз болады.

Түйін сөздер: эмигрант, эмиграция, эпистолярлық жанр, ұлт тарихы, эмигранттық журналистика, идеология, кеңес үкіметі, жанр, хат, көзқарас, тарихи дерек

$$
\begin{gathered}
\text { Karimova B., }{ }^{l} \text { Tuyakbayev G. } \\
{ }^{l} \\
{ }^{1,2} \text { Kyzylorda State University named after Korkyt Ata, } \\
\text { Kyzylorda, Kazakhstan }
\end{gathered}
$$

THE HISTORICAL SIGNIFICANCE OF THE LETTERS OF MUSTAFA SHOKAY 